\title{
NEWS/EDUCATION
}

\section{Forensic Medicine Teaching in Law and Medical Schools}

\author{
by
}

\author{
Harold L. Hirsh, M.D., J.D., F.C.L.M.
}

\begin{abstract}
The increasing importance of forensic mediclne to the attorney, physician and the publlc is apparent. People are constantly involved in medicolegal matters, and they engage the time, energy and skills of many attorneys, physiclans and others, particularly in malpractice and personal injury litigation. Thus, there is an obvious need for adequate education and training in forensic medicine of both lawyers and doctors. It is equally apparent that the best place to start the process is in the medical and law schools.
\end{abstract}

To investigate the current state of educational opportunities in forensic medicine in both law and medical schools in this country, information on such teaching was obtained from 149 approved and 30 non-approved law schools and 116 medical schools in the U.S. or their func. tioning divisions. The designation here of "forensic medicine" is used in its broadest meaning to include legal medicine, law and medicine, forensic or legal psychiatry, law and psychiatry and also forensic pathology, toxicology, serology or laboratory science.

The information obtalned yielded rather distressing data. Only 73 per cent of the approved and none of the non-approved law schoools offer courses in lorensic medicine. Sixty per cent of the medical schools provide some education in forensic medicine, but very few medical schools offer courses in torenand most of the courses that are offered are in a limited area of forensic medicine.

Most schools offer only one course in "law and medicine" and one in "law and psychiatry". A significant number offer only one of the courses. Where there is more than one course, they are invariably unrelated to one another. There are generally no prerequisites for the courses in forensic medicine in either of the professional schools. There is random exposure to forensic medicine rather than a planned program. Most of the courses, being limited and inadequate in scope, fail to give the student a complete overview of the field and the problems frequently confronting the attorney and physiclan in torensic medicine. Only a few merit a rating of excellent or good, and many must be considered no better than lair or minimal.

It is interesting that in medica and law schools a majority of the courses were presented in a lecture format, although the seminar approach was by no means infrequent. There appears to be an indication as to the considered relative value of forensic medicine in the curricula in that the greatest number of courses were allotted only a minimum of credit namely. two credit-hours. Significantly fewer courses were allotted as much as three credithours of great importance also is the expertise of those responsible for leaching the courses. In both professional schools the great majority of the teachers were educated primarily in their own discipline. Most had only on-the-job trainlng or experience in the other discipline. In the law schools particularly the pedological materlals were prepared by attorneys, while a significant amount of the teaching materials in the medical schools was of legal origin, the responsibility for presenting the courses was generally scattered nelter-skelter among various departments.

A number of problems account for the inadequacy of the educational opportunities in forensic medicine in law and medical schools. All schools have budgetary problems. Many are unwilling to engage part-time specialists in the broad area of forensic medicine, although generally the enrollment in such courses is high. Furthermore, there is a shortage and unavailability of trained or interested teachers in both discipllnes. Medical school administrators claim there is a lack of interest on the part of the students. If so. this is undoubledly explained by the lack of interest, concern, enthusiasm, urgency and feeling of necessity for courses in forensic medicine by the full-time teach- er, who is generally not exposed to medicolegal matters and hazards. What courses there are are not presented in the optimum manner and circumstances. They are usually elective and offered in the fourth year when the student is working on selected clerkships. Generally, the courses in both professional schools are designed so that the student is simply instructed how 10 practice his own profession by circumvention, or in spite of the other profession.

It is encouraging to find that among the professional societles of both disciplines, and particularly on an inter-disciplinary basis, there is significant activity toward developing an awareness of the problems as well as an elfort to find solutions.

There is a great need for each protession to have an understanding of the other discipline. However, it is questionable whether a random exposure to forensic medicine rather than a planned program is really beneficial. Students of one profession should be taught the methodology and ethics of the other prolession. Some insight into the mentality of the practitioner of each profession should be pre sented. The lawyer is the advocate for the client, and the physician has a comparable role to the patient. Their interests may at times be adversary, but they need not be mortal enemies.

Understanding and cooperation can be achieved. Law students shoutd be laught forensic medjcine in depth. Medical students should be familiar with the im. portance of forensic medicine. The studenl should be impressed with the lact that a patient is not simply a medical problem, but is lirst and foremost a human being complete with a considerable number of human rights.

The Author:

Or. Harold Hirsh currently serves as a Lecturer at George Washington University. American University and Howard University 